\title{
수직형 순환유동층 열교환기에서의 유체유동과 온도장의 수치해석 Numerical analysis of fluid flow and thermal fields in the vertical fluidized bed heat exchanger
}

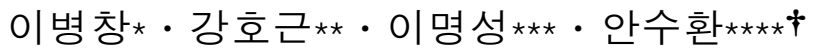

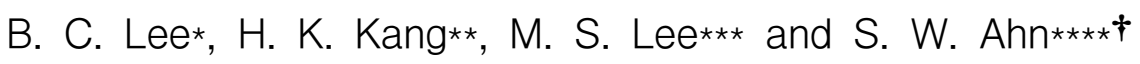 \\ (접수일 : 2012년 01월 09일, 수정일 : 2012년 05월 22일, 채택확정 : 2012년 05월 30일)
}

Key Words : Solid Particle(고체입자), Fluid Flow(유체유동), Vertical Shell-and -tube Type Heat Exchanger(수직 원통다관형 열교환기), Thermal Field(온도장), Fluidized Bed(순환유동층)

\begin{abstract}
The numerical analysis by using CFX 11.0 commercial code was done for prediction of fluid flow and thermal field in the vertical heat exchanger. The present experimental studies were also conducted to investigate the effects of circulating solid particles on the fluid flow and temperatures in the fluidized bed vertical shell and tube type heat exchanger with counterflow, at which the solid particles of glasses $(3 \mathrm{~mm} \Phi)$ were used in the fluidized bed with a smooth tube. The effect of circulation on the distance $(\mathrm{L})$ of tube inlet and baffle plate was also examined. The present experimental and numerical results showed that the particles in the distance (Ds) of $15 \mathrm{~mm}$ showed a more efficient circulation without stacked the space and the LMTD(Log Mean Temperature Difference) in the fluidized bed type was much lower than that in the typical type shell and tube heat exchanger.
\end{abstract}

\section{1. 서 론}

물 처리, 중합(polymerization), 생명공학, 그리고 식품가공과 같은 많은 산업공정 시스템은 이상(two phase)혼합의 순환유동층을 취급하는 경우가 많다.

순환유동층 기술은 열교환기 등의 스케일을 억제 하고 열전달계수를 향상시킬 수 있는 것으로 보고되 어 있다. 기체순환유동층의 연구는 광범위하게 행해 지고 있으나, 액체순환유동층에 관한 연구는 아직 초 보적인 수준에 불과하다. 고체입자순환유동층의 경 우 유체가 일정한 속도에 도달하면 고체입자에 작용 하는 항력은 고체입자 중량과 같아지므로 그 입자는 부유하거나 순환유동한다. 고체입자의 순환유동은 속 도가 증가할 수록 증가하고 종말속도(수직관에서 고

****† 안수환(교신저자) : 경상대학교 해양산업연구소 기계시 스템공학과

E-mail : swahn@gaechuk.gsnu.ac.kr, Tel : 055-772-9105 ***이명성 : 경상대학교 기계시스템공학과

*이병창 : 효성중공업 일반변압기설계팀

**강호근 : 선급협회 기술연구소
체입자가 벽에 충돌할 수 있는 최대속도)에 도달할 때까지 유체와 같이 행동한다 ${ }^{1)}$.

원통다관형 열교환기에서 순환유동층 구조는 종래 의 구조에 비해 두 가지의 잇점이 있다: i) 관 벽면의 스케일과 부식을 억제하고, ii) 열전달계수도 증가된 다. 이 같은 두 가지 잇점 때문에 순환유동층 원통 다관형 구조가 종래의 원통다관형구조보다 경제적 운전이 가능하다. $\mathrm{Klaren}^{2}$ 이 액체-고체 순환유동층 열교환기를 1970년 초기에 해수 담수화 장치에 적용 하였다. 그가 제안한 순환유동층 열교환기 구조는 한 개 이상의 튜브로 구성되고 수직튜브 내에서의 상향 유체가 고체입자를 상향시키는 구조이다. Richardson 등 ${ }^{3)}$ 은 액체-고체 순환유동층일 경우 단상유동일 경 우보다 열전달계수가 약 8배까지 상승함을 보였다.

$* * * * \dagger$ S. W. Ahn(corresponding author) : Department of Mechanical Engineering, Gyeongsang National University E-mail : swahn@gaechuk.gsnu.ac.kr, Tel : 055-772-9105 ***M. S. Lee : Department of Mechanical Engineering, Gyeongsang National University

*B. C. Lee : Hyosung Power \& Industrial Systems Performance Group

**H. K. Kang : Convergence Technology Research, Korean Register 
Haid 등은 순환유동층에서 고체입자가 포함되면 고체입자가 포함되지 않는 경우보다 순환유동층과 튜브 벽사이의 열전달계수가 크게 증가함을 보였다.

또한 고체입자가 포함됨 순환유동층 열교환기는 다양한 분야에서 오염발생을 억제하였다. ${ }^{5)}$

순환유동층 열교환기의 적절한 설계를 위해서는 순환유동층에 미치는 설계와 운전 파라메터를 아는 것이 필요하다. 그러므로 본 연구에서는 대향류 유 동을 갖는 수직형 순환유동층 원통다관식 열교환기 내의 유동과 온도장을 수치해석적으로 조사하였다. 순환유동층에 포함된 고체입자는 $3 \mathrm{~mm} \Phi$ 의 유리구 슬이다.

\section{2. 실험 장치 및 방법}

수치해석을 검증하기 위해 실험을 행하였다. Fig. 1 은 본 연구에서 제안한 순환유동층 열교환기 구조 이다. 좌측의 그림은 튜브내 유체가 일방향으로만 흐 르는 시중의 원통다관형 열교환기 구조이고 우측의 그림은 튜브 입구 앞에 구멍이 있는 배플을 설치하 여 튜브내 유체속의 고체입자들이 순환 유동하도록 하였다.
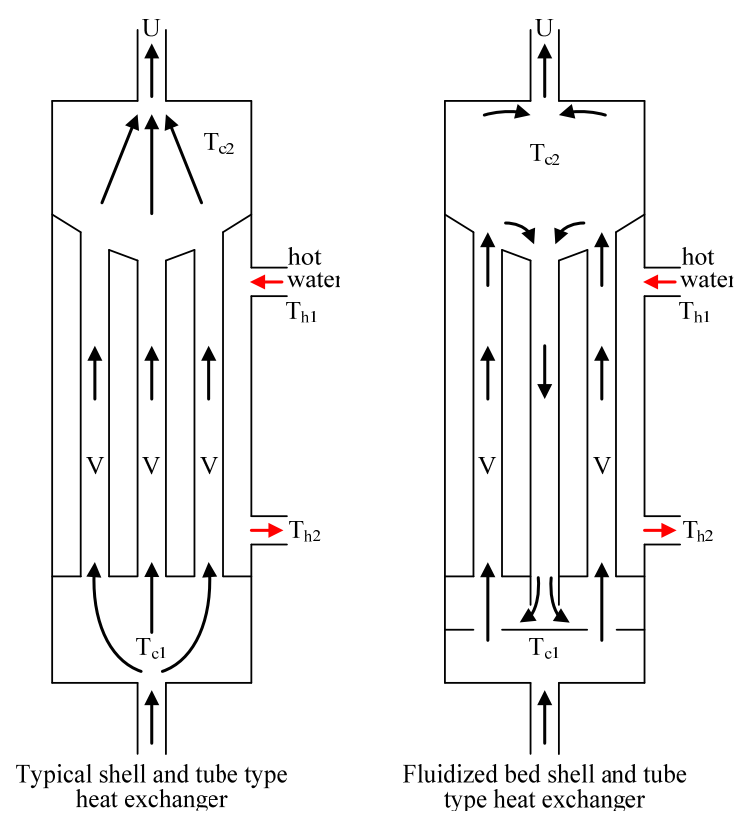

Fig. 1 Vertical liquid fluidized bed type and typical type shell and tube heat exchanger.

전체적 실험장치는 Fig. 2와 같다. 동일한 치수로 열전달 시험부와 가시화 시험부를 각각 제작하였다. 순환유동층에 포함된 고체입자는 $3 \mathrm{~mm} \Phi$ 의 유리
구슬(열전도도는 $1.2 \mathrm{~W} / \mathrm{m} \mathrm{K}$ 이고 밀도는 $2225 \mathrm{~kg} / \mathrm{m}^{3}$ ) 이다. 시험부 내의 고체입자 체적 비율은 $1.4 \%$ 이다. 고체입자는 튜브입구에 튜브 직경과 같은 크기의 직 경의 구멍을 가장자리 튜브 앞에만 설치함으로서 Fig.1의 우측 그림처럼 순환하게 된다. 고체입자는 상승할 때 유속에 따라 튜브 벽면에 충돌한다. 열교 환기 치수는 높이가 $705 \mathrm{~mm}$ 이고 셀의 직경은 80.4 $\mathrm{mm}$ 이다 튜브의 내경은 $14.2 \mathrm{~mm}$ 이다. 유체는 물을 사용하였고 유량은 바이패스 밸브로 조절하였고 유 량측정은 적층식 유량계로 측정하였다. 가시화 시험 부는 튜브 아크릴, 열 시험부는 스테인레스 강으로 제작하였다. 튜브측 입구와 출구온도는 각각 $26 \sim 2$ $8^{\circ} \mathrm{C}$ 와 $31 \sim 40^{\circ} \mathrm{C}$ 이다. 그리고 셀측 입구와 출구의 온 도는 각각 $83 \sim 75^{\circ} \mathrm{C}$ 와 $71 \sim 51^{\circ} \mathrm{C}$ 이다. 튜브측과 셀측 의 입출구에서 물의 온도는 $\mathrm{T}$ 형 열전대로 측정하였 다. Fig. 1 과 같은 순환유동층에 의한 튜브와 셀측 의 입출구 온도의 영향을 알기 위해 대수평균온도차 (LMTD)를 다음식과 같이 측정하였다.

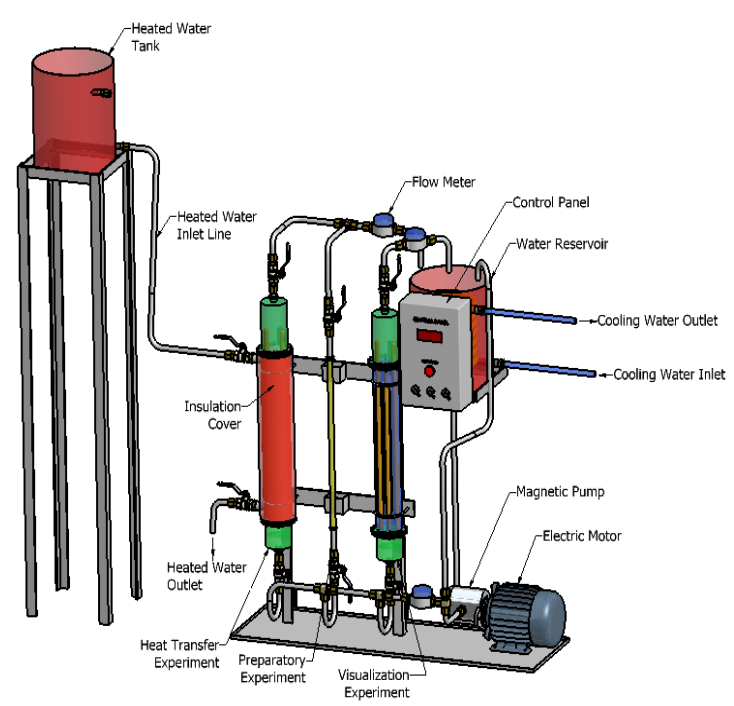

Fig. 2 Experimental apparatus with fluidized bed type shell and tube heat exchanger.

$$
L M T D=\frac{\left(T_{h 1}-T_{c 2}\right)-\left(T_{h 2}-T_{c 1}\right)}{\ln \left[\left(T_{h 1}-T_{c 2}\right) /\left(T_{h 2}-T_{c 1}\right)\right]}
$$

여기서 아래 첨자 $\mathrm{h}$ 와 $\mathrm{c}$ 는 셀측과 튜브측 유체이 고 1 과 2 는 입구와 출구이다.

\section{3. 수치 해석}

\section{1 입자 수송모델}

원통다관형 열교환기내 유동과 온도장에 관한 수 


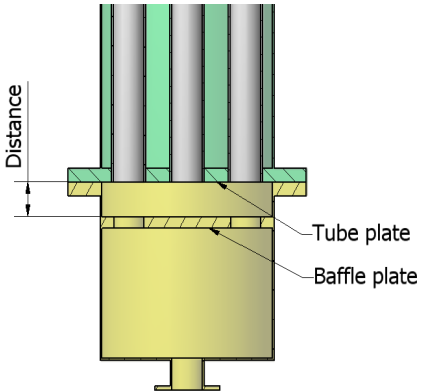

(a) distance between tube and baffle plate

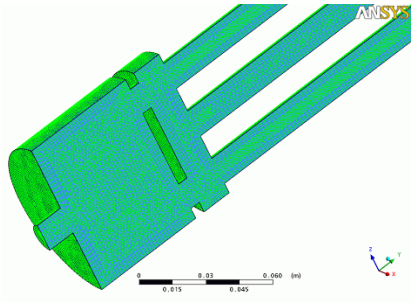

(b) lower side

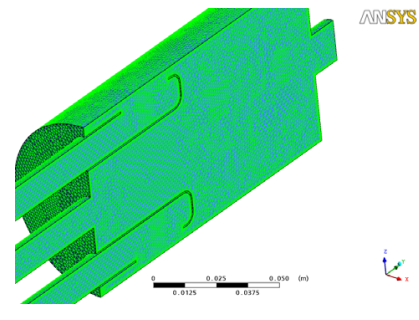

(c) upper side

Fig. 3 Configuration of test section for simulation.

치해석을 상용코드 CFX 11.0 를 이용하여 수행하였 다.작동유체는 물을 선택하였다. 입자수송 모델은 연속상(continuous phase)에 분리분포된 분산상을 모 델링할 수 있다. 이 모델링은 고체입자가 연속 상에 미치는 효과를 계산할 수 있는 소오스(source) 항을 가진 상(phase)을 분리 계산한다. 전체 입자상은 각 입자의 샘플에 의해 모델링 되었다. 입자의 추적 (tracking)은 각 입자에 대한 위치, 속도, 온도, 그리 고 질량에 관한 방정식으로 구성된 각 입자의 상미 분 방정식에 의해 수행되었다. 모든 연속상은 Eulerian model로 취급하였다. 연속 유체 매체에서 이동하는 고체입자를 고려해 보면, 고체입자 가속도 에 영향을 주는 입자의 힘은 고체입자와 유체간의 속도 차와 고체입자에 의한 유체의 이동거리에 의해 아래식과 같이 나타난다.

$$
m_{p} \frac{d U_{p}}{d t}=F_{D}+F_{B}+F_{R}+F_{V M}+F_{P}+F_{B A}
$$

여기서 $F_{D}$ 는 고체입자에 작용하는 항력이고, $F_{B}$ 는 부력이며, $F_{R}$ 은 도메인 회전에 의해 발생하는 힘, $F_{V M}$ 은 가상 질량의 힘, $F_{P}$ 는 압력힘, 그리고 $F_{B A}$ 는 Basset 힘 혹은 정상상태로부터 유동 패턴이 벗어 나는 이력 항이다. 모든 힘의 계산에서는 고체입자 가 놓여있는 지점에서 밀도, 점도, 그리고 속도와 같 은 많은 변수들이 필요하다.

식(2)에 의하여 유체가 점성항력과 고체와 유체 간 의 속도 차에 의해 입자 운동에 영향을 준다는 것을 보여 준다.

\section{2 전단응력 수송 난류 모델}

난류 응력과 난류 점성 $\mu_{t}$ 는 Mentor ${ }^{6)}$ 의 난류 전단 응력 수송 모델로 계산되었다. 이것은 $\kappa-\epsilon$ 과 $\mathrm{Wilcox}^{7)}$ 의 $\kappa-\omega$ 모델의 결합이다. 여기서 난류 와 주파수 $\omega$ 는 아래와 같다.

$$
\omega=\rho \kappa / \mu_{t}
$$

벽면에서는 난류 주파수 $\omega$ 가 난류 소산율 $\epsilon$ 보다 훨씬 정교하기 때문에 SST모델은 혼합함수 $F_{1}$ 가 1.0 이 되어 Wilcox 모델이 작용하고 벽으로부터 먼 지 점은 $F_{1}$ 가 0.0 이 되어 $\kappa-\epsilon$ 모델이 작용하며 아래와 같은 식으로 표현된다.

$$
\begin{aligned}
& \text { SST model }=F_{1}(\kappa-\omega \text { model })+\left(1-F_{1}\right) \\
& (\kappa-\epsilon \text { model })
\end{aligned}
$$

이들 변수 들은 항상 입자가 이동하고 있는 요 소를 계산하고, 요소 내 계산 지점을 계산하고, 그 리고 정점에서 입자 위치까지 보간(interpolation) 하는 이산 알고리즘의 형상함수를 사용함으로서 구할 수가 있다. 난유 운동에너지 $\kappa$ 는 다음과 같 이 정의된다.

$$
\partial_{t}(\rho \kappa)+\partial_{j}\left(\rho \overline{\nu_{j}} \kappa\right)=P+\left[\left(\mu+\frac{\mu}{\left.\sigma_{\kappa 1}\right)} \partial_{j} \kappa\right]-\beta^{*} \rho \omega \kappa\right.
$$

그리고 난류 와 주파수 $\omega$ 는 다음과 같다.

$$
\begin{aligned}
& \partial_{t}(\rho \omega)+\partial_{j}\left(\rho \overline{\nu_{j}} \omega\right)= \\
& \alpha_{1} \frac{\omega}{\kappa} P+\partial_{j}\left[\left(\mu+\frac{\mu}{\sigma_{\omega 1}}\right) \partial \omega\right]+\left(1-F_{1} \frac{2 \rho}{\sigma_{\omega 1}} \partial_{j} \kappa \partial_{j} w-\beta_{1} \rho \omega^{2}\right.
\end{aligned}
$$

Fig. 3은 Table 1의 수치 셋업(setups)을 이용한 수험부의 구성을 보여준다. 각 해석 형상에서는 각 각의 경우에 대한 유동상태를 고려하여 최적의 3 차 원 그리드를 생성하였다. 수치 그리드들은 육면체, 사면체, 각기둥들의 조합에 의한 메쉬들로 구성되었 다. 이러한 메쉬들로 관표면과 곡선표면의 경계층 구 조를 잘 표현할 수 있었다. 수치 결과는 그리드에 매우 의존적이기 때문에 충분한 정밀도와 균질성이 있는 그리드를 구성하기 위해서는 특별한 주의가 요 구된다. 
Table 1 Numerical conditions

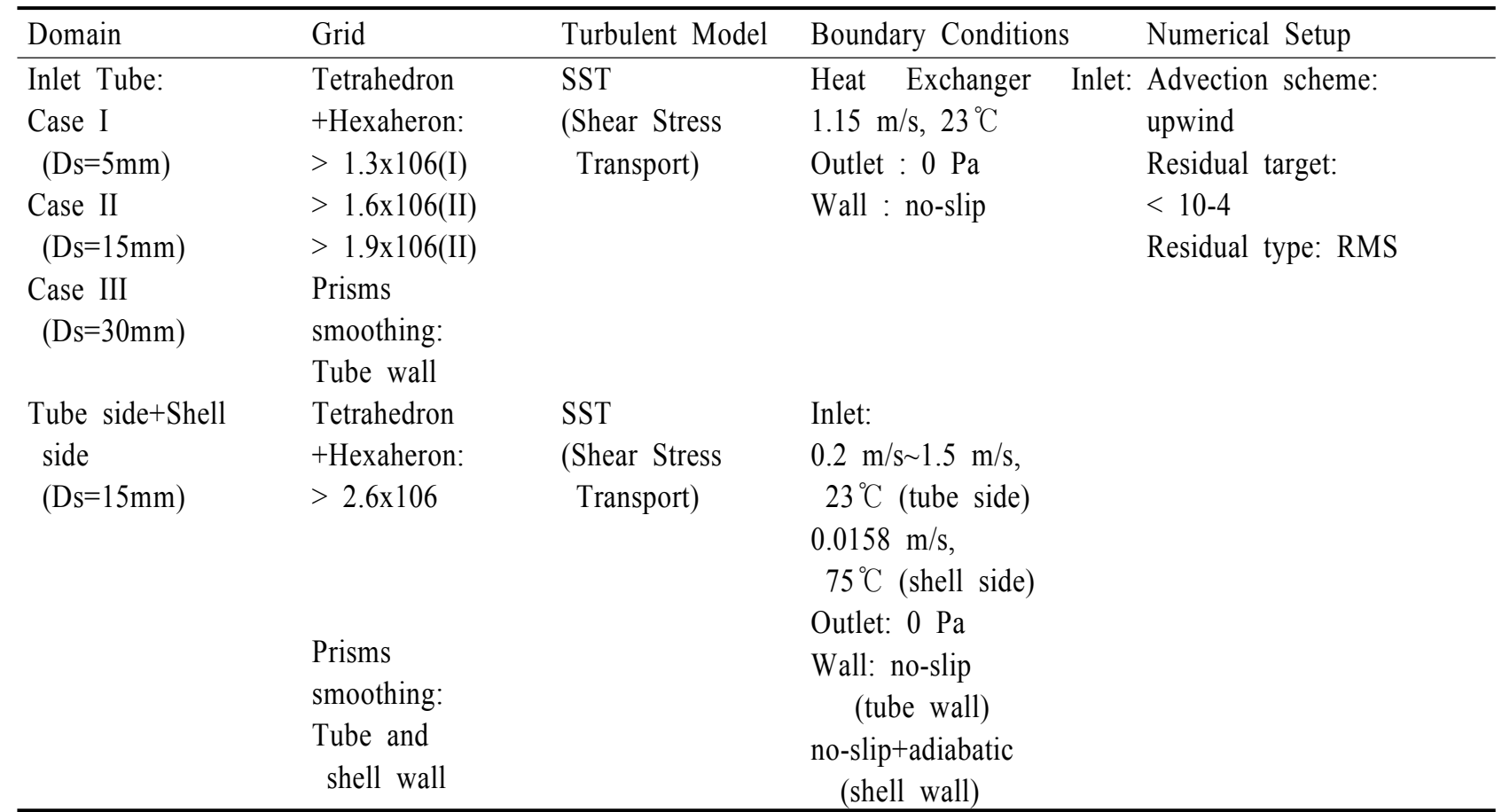

\section{4. 결과 및 고찰}

물과 같이 순환하는 고체입자( $3 \mathrm{~mm} \Phi$ 유리구슬)는
수직관벽을 주기적으로 충돌함으로서 벽면의 열 경 계층을 파괴하여 열전달율을 증가 시킨다. 특히 유 속이 낮은 경우 이러한 효과가 현저하다. 유속이 낮
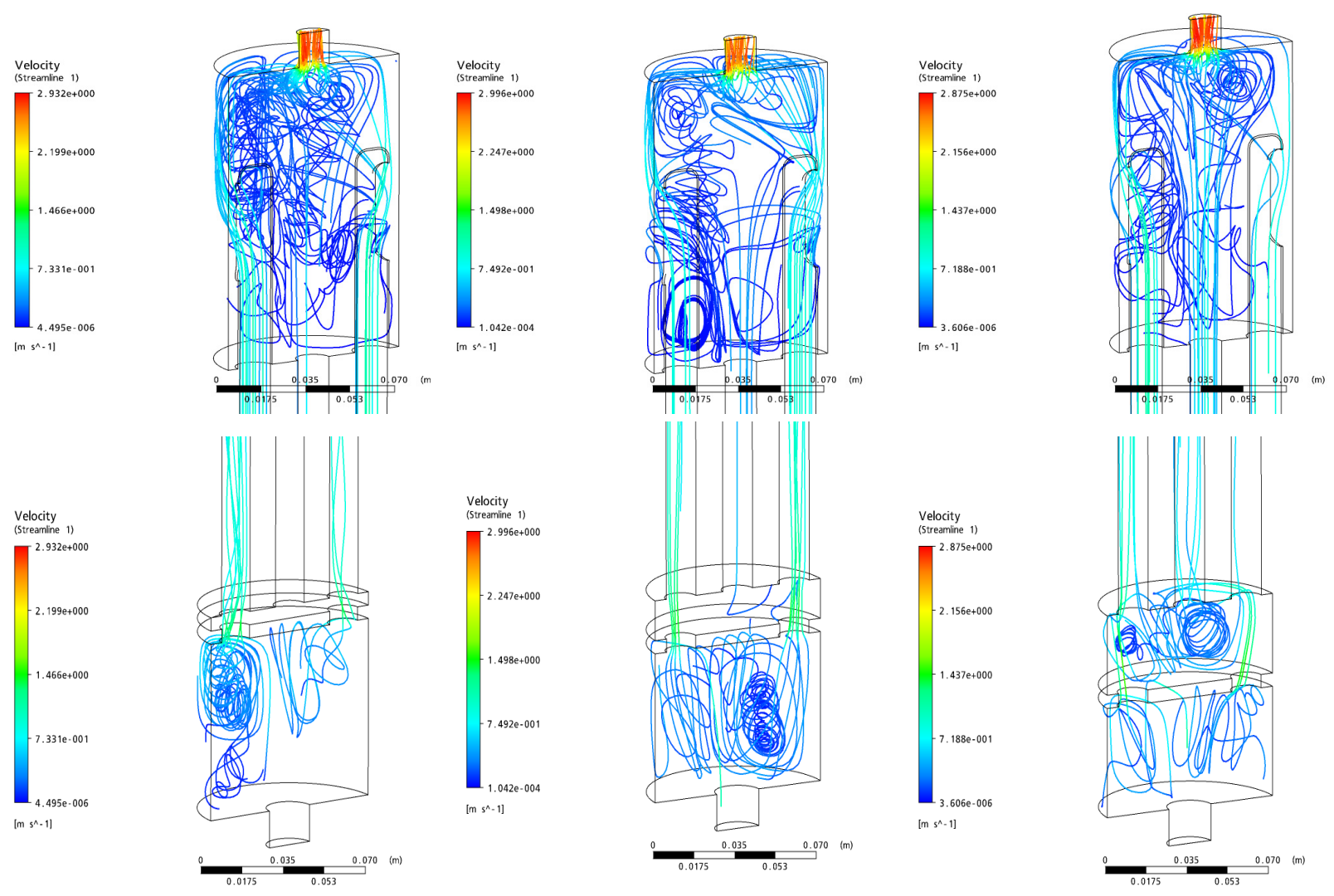

(a) $\mathrm{Ds}=5 \mathrm{~mm}$

(b) $\mathrm{Ds}=15 \mathrm{~mm}$

(c) $\mathrm{Ds}=30 \mathrm{~mm}$

Fig. 4 Streamlines in the tube sides for three different distances (Ds) at $u_{w}=1.154 \mathrm{~m} / \mathrm{s}$. 
으면 고체입자의 벽면 충돌 주파수가 증가하여 고체 입자에 의한 열전달율이 상승한다. 본 연구에서는 고체입자가 수직관벽을 충동하는 유속의 범위는 $0.346 \mathrm{~m} / \mathrm{s} \sim 1.0 \mathrm{~ms}$ 이었다.

Fig. 4는 열교환기 입구의 유속이 $1.154 \mathrm{~m} / \mathrm{s}$ 인 경 우 Fig. 3의 튜브와 배플판 간의 거리(Ds)가 순환유 동에 미치는 효과를 시험하기 위해 3 종류의 거리 $(\mathrm{Ds}=5 \mathrm{~mm}, 15 \mathrm{~mm}$, 그리고 $30 \mathrm{~mm}$ )에 대해 수치해 석한 유선을 보여준다. Fig. 4(c)의 $\mathrm{Ds}=30 \mathrm{~mm}$ 인 경우 3개의 튜브 중에서 가운데 튜브내의 유속이 양 측면 튜브 내의 유속 크기의 $80 \%$ 에 도달하면 가운 데 튜브 측으로 상승하는 유체 속도가 증가하여 입 자의 순환이 일어나지 않는다. 특히 $\mathrm{Ds}=30 \mathrm{~mm}$ 처 럼 충분한 간격이 있을 경우에는 낮은 속도에서도 가운데 튜브 측으로 상승류가 일어난다는 것을 의미 한다. 그러나 $\mathrm{Ds}=5 \mathrm{~mm}$ 경우에서는 많은 고체입자 들이 튜브와 배플판 사이에 적층되며 가운데 튜브에 서 상승류가 발생하지 않고 Fig. 1의 오른쪽 그림처 럼 전적으로 순환유동이 일어난다. 그러나 배플판 위 에 적층된 유리입자가 유동저항을 방해한다. 마지막 으로 $\mathrm{Ds}=15 \mathrm{~mm}$ 인 경우 고체입자가 양측면 튜브 벽면을 충돌하며 상승한뒤 가운데 튜브를 통해 하강 하고 튜브와 배플판 사이에는 다량의 고체입자가 쌓 이지 않는 순환 유동이 일어난다. 해석 결과 $\mathrm{Ds}=$ $15 \mathrm{~mm} 20 \mathrm{~mm}$ 가 가장 적절하였다.

Fig. 5는 원통다관형 열교환기에 유입되는 물의 유 속이 $1.154 \mathrm{~m} / \mathrm{s}$ 이고 $\mathrm{Ds}=15 \mathrm{~mm}$ 인 경우 운전 시작 후 15초와 45초의 튜브측 스냅모습(snapshot)과 온도

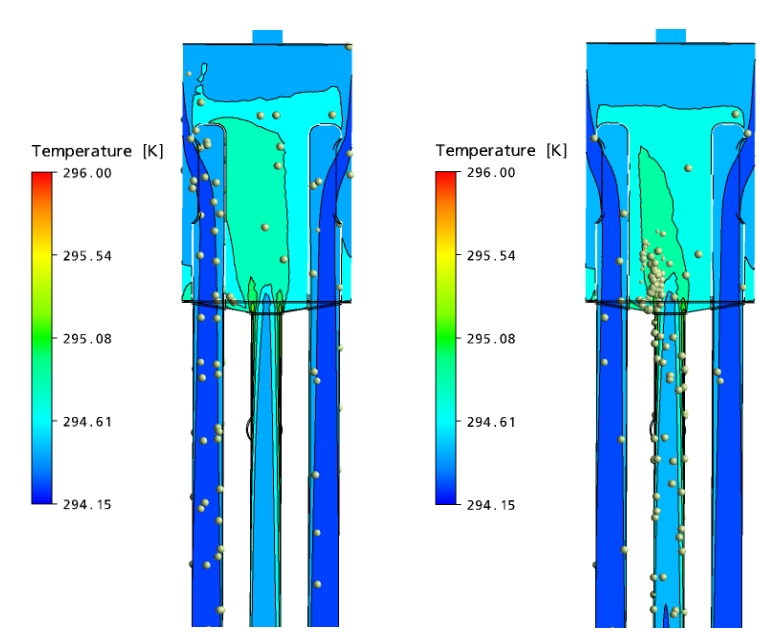

(a) 15 sec. after starting

(b) 45 sec. after starting

Fig. 5 Continuous snapshots of temperature and particle distributions in the tube sides

분포이다. 3 개의 튜브 중에서 가운데 튜브에서도 물 이 상승유동아고 있음을 보여준다. 그러나 가운데 튜 브에서 상승류의 유속은 유리의 고체입자를 상승시 킬 수 있는 최저 속도인 $0.346 \mathrm{~m} / \mathrm{s}$ 보다 훨씬 적기 때 문에 고체입자는 측면 튜브로 상승하여 가운데 튜브 로 하강하는 순환유동이 발생한다.

운전시작 45초 이후는 가운데 튜브 측에 고체입자 들이 밀집된 것은 양측면 튜브로부터 빠른 속도로 상승한 고체입자들은 가운데 튜브로 하강하며 가운 데 튜브로 낮은 속도의 상승류 때문이다.

Fig. 6은 셀측에서 뜨거운 물이 대향류로 흐르는 경우 유선(a,b)과 온도분포(c)를 각각 나타낸다.

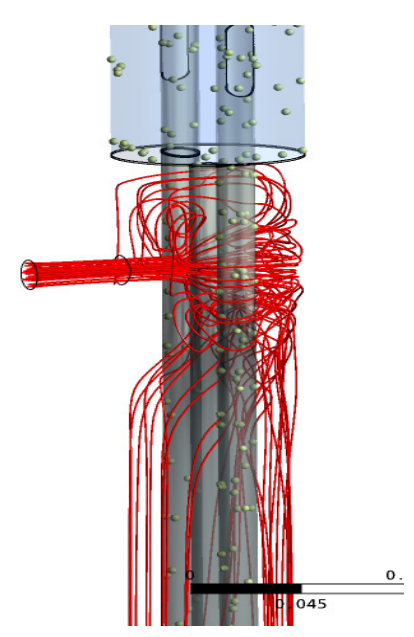

(a) inlet

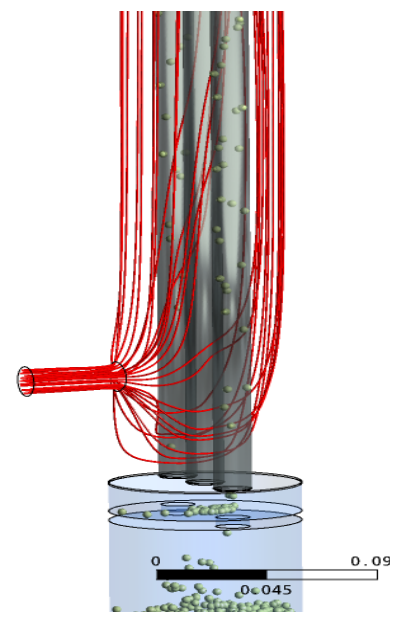

(b) outlet

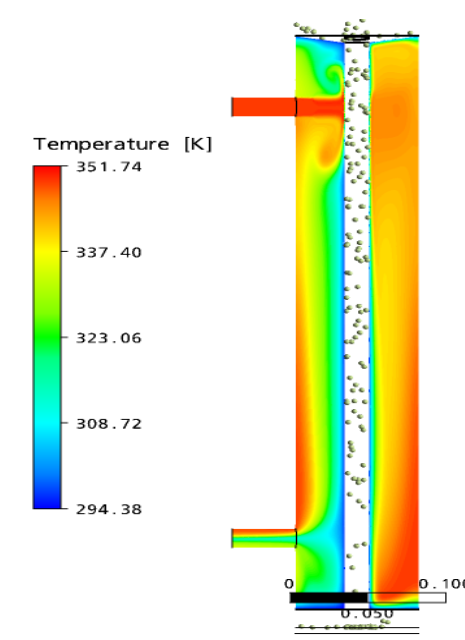

(c) shell side

Fig. 6 Flowfileds of hot water in shell side: streamlines at inlet(a), outlet (b), and temperature distribution (c). 


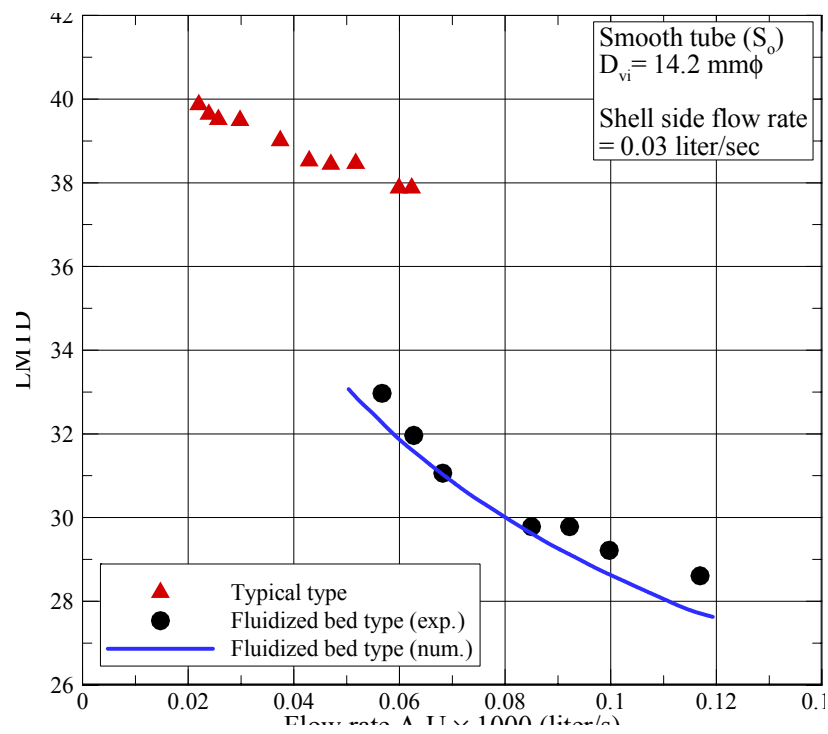

Fig. 7 A Comparison of LMTDs between the commercial type and fluidized bed type.

운전이전에는 모든 고체입자들이 열교환기 입구의 $\mathrm{U}$ 자관에 쌓여 있다. 운전이 시작되면 튜브측의 차가 운 물은 고체입자와 같이 열교환기 입구 슬롯(slot) 을 통해 유입된다. Fig. 6(c)의 온도분포에서는 셀측 에서는 유입과 유출구가 있는 앞측보다 반대측에서 온도가 높았다. 이는 Fig. 6(a)처럼 셀 입구측에서 유입되는 고온 고압의 물이 3 개의 튜브들을 관통하 여 뒤쪽으로 유동하고 셀의 출구까지 유동하는 동안 고온의 유체가 튜브들의 저항 때문에 튜브 앞쪽으로 유동하기 어렵기 때문이라 사료된다.

Fig. 7은 대향류의 원통다관형 열교환기에서 Fig. 1 의 왼쪽 그림과 같이 배플을 설치하지 않은 시중의 원통다관형 열교환기와 Fig. 1의 오른쪽 그림처럼 튜 브입구에 구멍이 있는 배플을 설치한 순환유동층 원 통다관형 열교환기에 대한 대수평균온도차(LMTD) 들이다. 배플은 튜브의 직경과 동일한 크기의 2 개구 멍을 제작하고 그 구멍은 양측면 튜브의 위치와 일 치 시켰다. 대수평균온도차는 배플을 설치한 순환유 동층 구조가 배플을 설치하지 않은 시중의 열교환기 구조보다 훨씬 적었다. 대수편균온도가 적은 것은 열 전달 성능이 우수함을 의미하고 이는 열교환기내에 서 유체의 순환이 발생하므로 튜브측 입구의 유체온 도가 상승하기 때문이다. 그러므로 순환유동층 시스 템은 시중의 열교환기보다 열교환기 크기를 감소시 킬 수 있다.

\section{4. 결 론}

상용코드를 이용하여 열교환기내 난류유동과 온도 분포를 수치해석하였다. 검증을 위해 대수평균온도 차를 실험적으로 조사하였다. 얻어진 주요한 결론은 다음과 같다.

1) 내측 튜브와 배플간의 거리는 $15 \mathrm{~mm} 20 \mathrm{~mm}$ 일 때 가장효율적인 순환유동이 발생하였다.

2) 순환유동층 구조가 기존의 구조보다 대수평균 온도차가 훨씬 작았다. 이는 순환유동층의 경우가 열전달 성능이 우수함을 의미한다.

3) CFX 11.0 상용코드를 이용하여 고체입자가 포 함된 순환유동층 원통다관형 열교환기 내의 유선과 온도분포를 수치화하여 최적화된 열교환기 설계를 예측할 수 있었다.

\section{참고 문헌}

1. Bird, R. B., Stewart, W. E. and Lightfoot, E., 1960, Transport Phenomena, John Wiley and Sons Inc., NewJersey, USA.

2. Klaren, D. G., 1975, Development of a Vertical Flash Evaporator, Ph. D. Thesis, Delft University of Technology.

3. Richardson, J. F., Romani, M. N. and Shakiri, 1976, Heat Transfer from Immersed Surfaces in Liquid Fluidized Beds, Chem. Eng. Sci., vol. 31, pp. 619-624.

4. Haid, M. V.. and Mŭller-Steinhagen, H., 1994, Heat Transfer to Liquid-Solid Fluidized Beds, Chem. Eng. and Proc., vol. 33, pp. 211-225.

5. Rautenbach, R. and Katz, T., 1996, Survey of Long Time Bahavior and Costs of Industrial Fluidized Bed Heat Exchangers, Desalination, vol. 108, pp. 335-344.

6. Menter, F. R., 1993, Zonal Two Equation $\kappa^{-\omega}$ Turbulence Models for Aerodynamic Flows, AIAA Paer. 98-0522.

7. Wilcox, D. 1986, Turbulence Modeling for CFD, DCW Industries Inc., La Canada, CA. 